\title{
Rumah Daulat Buku: The Power of Literacy and Education for ex Terrorism Convict
}

\author{
$1^{\text {st }}$ Khamami Zada ${ }^{1}, 2^{\text {nd }}$ Fathudin $^{1}, 3^{\text {rd }}$ Dewi Khairani ${ }^{2}$ \\ \{khamami@uinjkt.ac.id ${ }^{1}$, fathudin.fsh@uinjkt.ac.id ${ }^{1}$, dewi.khairani@uinjkt.ac.id²\} \\ UIN Syarif Hidayatullah, Sharia Department ${ }^{1}$, UIN Syarif Hidayatullah, Informatics, Jakarta, \\ Indonesia $^{2}$
}

\begin{abstract}
Some people say that the low literacy ability of Indonesian people is one of the causes of the rise of radicalism. Reading and writing should be a culture that is familiar to everyone, because these two things become the essence as well as being a tangible form of their quality. By reading someone will open the window of the world and by writing someone can also pour out the awkwardness that is in the mind and himself. Rumah Daulat Buku (Rudalku) is a de-radicalization program implemented by the National Sovereign Institute by building libraries in the homes of the Brotherhood who have been exposed to radicalism. This research presents an idea of Rudalku activities that focus on efforts to reduce the understanding of radicalism.
\end{abstract}

Keywords: digital literacy, information literacy, digital divide

\section{Introduction}

The concept of a literacy strengthening campaign as an attempt to deradicalize for example has been carried out by a Sovereign National Institution which was founded in 2011. Through this institution the Rumah Daulat Buku (Rudalku) was also founded in 2017. One of Rumah Daulat Buku's initiators took a positive step in Islamic socialization by encouraging former Terrorist Prisoners to return to a more positive course. Different attempts have been made so far as attempts to deter and deradicalize terrorism are being focused based on topdown policies. Governing policies or related bodies are crucial. While the bottom up program has not been realized too much, moreover a program initiated and supported by ex-marriages themselves. The National Sovereignty Institution, moving on from that notion, proposed an offer of a definition, namely the establishment of the Rumah Daulat Buku which was operationally directly sponsored by ex-marriages. The reading house is intended to serve as a new social place for them to engage in the local community where they live. The Lembaga Daulat Buku's presence in ex-maritime homes is considered to be a way to achieve excombatant terrorism in the social climate in which they reside. They are also supposed to be agents of change for the society who can improve critical thinking so that people are not easily caught in radicalism and terrorism entanglements.

Deradicalization[1] efforts are often likened to diagnostic efforts to radical "disease" that a person has and then to seek appropriate treatment. Accuracy can be related to the type of medicine, its dose, and also how to treat it. However, the stages of deradicalization that are passed systematically are often still "bounced" by the ferocious "virus" that wraps someone, even though they have involved experts who are experts in diagnosing, reinforced by 
experienced research and action teams and supported by large funds. But in reality, radicalism is still growing and terrorism is still a threat. Our previous work[2] explain constructive actions in the context of deradicalization of suspected terrorist prisoners to prevent the radicalization process that is rife via the digital world.

In addition to individual understanding of religious teachings, the level of superhero delusions in a person also plays a role in this phenomenon. Everyone has this tendency, although to varying degrees. When there is a desire to participate to be able to change society, eradicate crime quickly, that is the tendency of superheroes. To a certain degree the tendency of superhero delusions is categorized as normal, because humans are social creatures. However, it becomes abnormal when the levels of superhero delusions are excessive. There is an inner urge to change the social order so that order can occur in accordance with the desired personal perception quickly. Radical action is taken to realize it all. In fact, sacrificing his own life was willing to realize his target. Such superhero delusions can be called already in the acute phase[3]. Believed to be rewarded by an angel, entering heaven is only true seasoning which completes the delusions of acute superheroes. In certain cases, this can be a precise lighter in carrying out radical actions. When these internal variables accumulate, especially driven by external factors, the potential for the rise of acts of terrorism will be even higher. Based on such understanding, the handling of the problem of terrorism is indeed not enough through law enforcement alone. Law enforcement efforts are responsive steps, while terrorism itself has progressive and dynamic characteristics.

The Surabaya bombing that occurred in May 2018 has become a new phenomenon in the study of terrorism. The action carried out by involving one family, including children who are school-age children, increasingly emphasizes how vulnerable the family is to be the target of the indoctrination of terrorism ideology. The phenomenon even shows that terrorists are able to radicalize all family members. Family ties can accelerate the process of radicalization, because in family relationships, there is love, trust or trust, and willingness to sacrifice. That way, they are difficult to betray because they have a family relationship. Likewise, the involvement of women and children in acts of terror is also because women and children tend not to be suspected or examined by the authorities.

Such reality, it seems to make us aware that the prevention of terrorism, in addition to taking action by taking action must also be preventive measures so that exposure to the ideology of terrorism does not continue to develop. Efforts to reduce terrorism must be a synergistic step with the involvement of the state and civil society to suppress symptoms from upstream to downstream. In addition, the handling of terrorism must also touch the root of a substantial problem that is how to break the chain of ideology of understanding the teachings of false religion. Ideology, citing Hotmatua, has a strong influence that can explain the actions of individuals and groups. Engraved a dictum "ideology determines who the enemy". Ideology also has a long justification for political action. The worldview has guided decisions and actions, both with violence and without violence[4].

The presence of Rumah Daulat Buku can be one of the efforts of deradicalization which is not merely ceremonial and celebration. With the tagline "Many Reads Become Open, Many Readings Become Tolerant". This reading house is present on the basis of a thesis that one that makes a person vulnerable to radicalism is the lack of reading power. Narrow insights make it easy for someone to accept the doctrine. When exposed to the logic of extremism, those recruited in the circle will feel that their thoughts and actions are the most correct and ignore the comparison ideas. Because of that there needs to be literacy to break the chain of ideology of terrorism. Then came the idea of a literacy approach for ex-convicts of terrorism with a strengthening movement to read books. The emergence of a special ex-maritime literacy 
approach, as practiced by the National Sovereign Institute, can be a pioneer of deradicalization in an innovative way.

\section{Literacy Education in Indonesia}

Some people say that the low literacy ability of the Indonesian people is one of the causes of the rise of radicalism. Reading and writing should be a culture that is familiar to everyone, because these two things become the essence as well as being a tangible form of their quality. By reading someone will open the window of the world and by writing someone can also pour out the awkwardness that is in the mind and himself. There is a thesis that radicalism can expose a person due to low interest in reading. The more a person reads, the more possible for him to open up his insights and knowledge so that he is not easily influenced by destructive radical notions. Reality also shows that one of the challenges faced by Indonesia is the challenge of literacy shallowness, one of the indicators is the low interest in reading society. When referring to the data version of PISA (Program for International Student Assessment)[5], Indonesia ranks 64th out of 72 countries. While the version of The World Most Literate Nation Study, Indonesia ranks 60th out of 61 countries.

It also reveiled while the number of Internet users in Indonesia has reached 132.7 million people from 256.2 million people of Indonesia's population. This means, Internet users in Indonesia have reached $51.8 \%$ of the total population of Indonesia. The fact shows, the large number of Internet users in Indonesia, as well as the high frequency of accessing information content and social media, does not necessarily guarantee the 'maturity' of Indonesian netizens in using the Internet. In addition to the gaps that occur, various cases of Internet abuse are also rife, ranging from internet fraud, addiction or addiction, violations of privacy, reality bias, to the most recent is the expansion of hoaxes. If examined, a number of these cases lead to one thing, namely the low digital literacy of Indonesian society.

Advances in information technology have actually made it easier for the public to be able to absorb information and knowledge such as through internet facilities. However, challenges arise when the internet has also been met by Islamic narratives that are not authoritative and can be justified. Likewise, Islamic material available on the internet is also vulnerable to being charged with radicalism content, thus allowing a person the opportunity to be exposed to radical ideas. Radicalism, if it is still in the form of a personal appreciation of a particular religion or belief, as long as it does not negate the understanding of others, actually does not matter because it is an expression of one's totality in religion. Likewise, when an individual is educated and has a breadth of reading, it is increasingly impossible to behave narrowly or radically because in his view truth is relative, depending on which perspective he sees. In this context, education and literacy movements, axiologically, equip people to accept the reality of difference as a logical consequence of the inevitability of life that is blessed by God.

\section{Methods}

This research was conducted by interview and direct observation. This study uses descriptive qualitative methods with secondary data sources and data collection techniques that are done with documentation. The results of this study indicate that the literacy movement can be an agent of change for the surrounding community to create a moderate and tolerant 
society. The main purpose of using qualitative research is to understand social phenomena or phenomena in ex-napitles by focusing more on a complete picture of the phenomena studied rather than breaking them down into interrelated variables. The hope is that a deep understanding of the deradicalization program is obtained by utilizing the literacy movement to produce a theory. Because the objectives are different from quantitative research, the procedures for data acquisition and the types of qualitative research are also different.[6]

\section{Rumah Daulat Buku}

Soffa Ihsan founded the Rumah Daulat Buku (Rudalku) with former terrorist convicts (napiter). With high militancy, he tried to encourage ex-military to want to establish a Rumah Buku in his house. No need to make a special place that will only cost a lot. The ex-maritime house can be a suitable place for a reading garden and build creations and endeavors that are significantly beneficial to residents and surrounding communities. From there the maritime agents can also be agents of change for the surrounding community to realize a moderate and tolerant society through the literacy movement. Soffa's step was even better when in September 2017 met with Kiagus Muhammad Toni in Ogan Komering Ilir Regency (OIC). Toni was once involved in the Palembang terrorist network which was under the command of Jemaah Islamiyah (JI). At that time, Soffa Ihsan then invited Kiagus Toni, who was just free to establish Rumah Daulat Buku (Rudalku). A good reception from Kiagus Toni made Soffa Ihsan then send a number of books to fill the library shelves at Kiagus Toni's house. When Kiagus Toni sent a photo while inviting children to read in his home, Soffa Ihsan was touched.

One time, Kiagus Toni came to the Rudalku headquarters in Pasar Minggu, Jakarta. The former napiter brought Ani Sugandhi from Palembang and Khoirul Ikhwan from Madiun. Ani Sugandhi himself was once involved in the JI network in the South Sumatra region, while Khoirul Ikhwan was arrested for planning to blow up the Myanmar embassy in 2013. During a visit to the Rudalku secretariat, the two agreed to establish a literacy movement under the auspices of the Rudalku. At the end of 2017, the Rudalku movement attracted Abdurrahman Taib, a former South Sumatra network JI activist who had been trained directly by Noordin M. Top. Taib agreed to join the literacy movement. So that in 2017 there have been 4 branches of Rumah Daulat Buku in several regions. Even in 2018 there have been around 17 Rudalku that were successfully established by Soffa Ihsan together with ex-military forces spread across a number of regions namely Jakarta, West Java, East Java, North Sumatra (Medan), and South Sumatra (Palembang). This number will continue to grow thanks to the enthusiasm, diligence, and perseverance of approaching ex-napites to establish the reading house.

Some of the books that were read in the recitation activities held by Soffa Ihsan at his home include the book of al-Uzwah lil 'Alamin , al - dalil al - Irshadi Ila Maqasid al - Shari ' ah al - Islamiyyah by Muhammad K. Imam. The content of the lecture delivered does emphasize Islam as a religion of peace. The Ustadz who was presented to fill the studies were also sometimes ex-napiter, such as Ustadz Sufyan Tsauri, Ustadz Imam Nakhoi and even had even been filled by former Mantiqi III Commander of Jemaah Islamiyah, Nasir Abbas. According to Soffa Ihsan, his party deliberately planted a message of peace to former terrorist inmates. He hopes that ex-terrorist inmates can get knowledge from the study. Soffa said that this was done so that the ex-terrorist prisoners could gain knowledge so they would not be exposed to radicalism again. "The point is we invite them to love knowledge. So, if you want to jihad, you have to use science to not get lost". 


\section{Discussions}

Most of the ex-combatants are still strong radical ideologies that are embedded in his head. The radical doctrine infused by previous mentors is still firmly rooted even at a much lower level after participating in programs organized by the National Sovereign Institution. Most of them are still easily emotionally ignited when absorbing information and narratives on social media that smells radical, even though the information is sometimes hoax information. In Soffa's view, they do not have critical reasoning because they do not have the capital of knowledge in identifying various wild information in the virtual universe. Soffa still believes that people can become radical because of lack of reading.

The literacy approach carried out by the National Sovereign Institution through the Rumah Daulat Buku program is considered by Said Aqil Siradj as one form of criticism of the approach that has been used so far for de-radicalization that does not touch the "head contents" and unconsciously ignores the potential of ex-napiter as a human being who one day can change. Conversely, so far the de-radicalization approach actually looks more to make the exnapiter a "body without soul" which only performs the "rituals" of the norm without growing awareness of them to be encouraged to become mobilizers.

According to Said Aqil, this literacy approach is a portrait of the civilian movement. Civil society has been proven capable of carrying out a series of activities that the state has not or have not done in relation to institutions serving the interests of the wider community, or at least being an alternative discourse outside the state bureaucracy apparatus in carrying out deradicalization programs. In the current and future situation, the role of non-state actors is increasingly recognized and the role is real, which can have powers that can rival the power of the state. Extremism has become a serious threat to the country. This disease can infect anyone who always fosters a symbolic religious attitude that is dry from spiritual appreciation. Well, the endeavor that needs to be put forward is the need to re-cultivate the "scientific tradition".

The steps taken by the Daulat Bangsa Institute also confirm Ian Chalmers' research results in Countering Violent Extremism in Indonesia: Bringing Back the Jihadists (2017) - the success of the process of deradicalization is more likely to be placed on community-based actions. According to Chalmers, although official efforts in Indonesia to control the behavior of extremists were quite successful, some ex-jihadis remained bound to militant thinking. The return of hundreds of militant activists who support ISIS abroad has implications for the need for interventions to prevent radicalization and reintegration of ex-jihadists into society[7]. What is done by the National Sovereignty Institution through the Rumah Sovereign Books program is a step in the de-radicalization carried out by civil society forces which emphasizes more on approaching ex-jihadists and radicals, then invites them to make friends, and then engages in activities that are beneficial to the community, one of which is by establishing reading houses.

Functionally, Rumah Daulat Buku can be likened to Community Reading Gardens (TBM) in general. Its existence can be an alternative learning center in order to increase children's interest in reading. Read the home can also be a central source of knowledge which has a strategic role to create a society with interest and cultured reading (reading society) high . This step can be an effort to de-radicalize families and children who commit terrorism. The presence of the Daulat Buku House as a form of Community Reading Park is a real action of ex-military to participate in building critical awareness of the community. The existence of the Book House, which was initiated by ex-prisoners, can at least facilitate both the children and children of the local residents to get their world, which is the world of learning. When they feel comfortable with their world, eating will be difficult to be influenced by radical notions. 
Community literacy plays an important role in efforts to reduce the exposure to radical understanding, especially for children. All this time, terrorism has been motivated by a particular ideology which is the basis of why acts of terrorism are intensified. Terrorism also departs from the concept of the mind which carries the name of a particular dogma so that it still continues to this day. It spreads the virus through the doctrinaire-revolutionary actions of a group of people. In this context, education can play a role in stemming terrorism through educated common sense. During this time, the perpetrators of terror who in their actions are often with the legitimacy and justification of religion as justification, are actually infected with the disease of non-titration (illiterate). Non-literacy is not a matter of how many books are read, but rather how it locates and criticizes the texts it reads.[8]

The pattern of reading texts without critical awareness, instead of bringing illumination of mind, instead what happens instead gives birth to an attitude of "short axis." On the one hand he is also "hegemony" by the dogma he gets from his group. It loses "sovereignty" over its critical power. This situation is reminiscent of doctrines of violence that have nothing to do with certain religions or beliefs, but rather how to "read and criticize" the text more deeply. Here the literacy intelligence thesis departs. Schools, therefore, can construct a special learning based on critical literacy skills. The form of learning can vary depending on the concept of national government policies and the creativity of teachers in the classroom.[8]

Education for children can certainly start from the family, then continue through school to university level. One simple thing that is important to instill in children is to read a lot while discussing what they read. It is not limited to reading to feed information, but is trained to build critical power over what is read. Parents make it possible to teach the method continuously so that the child's "home of understanding" continues to build and has a strong foundation. The more periodic children are taught how to read and understand what they read, the more understanding of the dangers of terrorism. This kind of learning becomes important to protect yourself from terrorism banality. Moreover, such informal education is suspected to be the most effective way to educate children than the realm of formal and non-formal education.[8]

The concept of anti-terror education in the family environment can work well if it is supported by the central government as a regulator. The government can arrange a set of concepts and their praxis methods to protect children from the banality of terrorism which is currently worrying the public. The national strategic references are expected in turn to be a reference for parents. Thus, cooperation between civil society, members of the community (family) and the government should proceed dialectically so that children can be shielded from the effects of terrorism.

The problems most of which are faced by ex-marriages so far are indeed related to economic problems. In fact, according to Soffa Ihsan, some book sovereign houses managed by ex-marriages are still contracted. Variants of their profession are ngojeg, selling herbal medicines or other odd jobs. Due to poverty and disability factors, their children's educational needs are met with homeschooling methods, although these methods are also felt by many of their weaknesses, especially because of the development of the business world and global challenges require children to have skills as a provision for their future. 


\section{Conclusions}

Rumah Daulat Buku, which was initiated by the Daulat Bangsa Institute together with exmaritime leaders in the future, will provide capacity building for the ex-maritime administrators of Rumah Daulat Buku, especially in the provision of building a library, building social reintegration and how to build a literacy society. Soffa Ihsan also planned for a training that was intended for ex-prisoners and family members. In the future, the Daulat Buku house is expected to be an activity for local residents, especially teenagers and children, to have the opportunity to express their expressions and creations in the form of non-formal educational activities but remain free and cheerful. For Soffa, ex-maritime people are basically human beings who have the potential to participate in efforts to empower the community, especially by transforming the reading he has pioneered into media for them and the community as an effort to deradicalize and prevent the threat of radicalism and terrorism.

Acknowledgements. This research supported by UIN Syarif Hidayatullah Conference Grant for ICONQUHAS 2019

\section{References}

[1] D. Koehler, "Understanding Deradicalization: Methods, tools and Programs for Countering Violent Extremism," Eur. Heart J., 2006.

[2] K. Zada, Fathudin, D. Khairani, and Y. Durachman, "Reduce Extremism through Digital Literacy," 2020.

[3] P. Thomas, "Failed and friendless: The UK's 'preventing violent extremism' programme," $B r$. J. Polit. Int. Relations, 2010.

[4] H. Paralihan, "Islam dan Demokrasi: Menguatnya Politik Identitas Ancaman Kemanusiaan di Indonesia," Aqlania J. Filsafat dan Teol. Indones., 2019.

[5] K. Stacey, "The PISA view of mathematical literacy in Indonesia," J. Math. Educ., 2011.

[6] M. Rahardjo, "Metode pengumpulan data penelitian kualitatif," 2011.

[7] I. Chalmers, "Countering Violent Extremism in Indonesia: Bringing Back the Jihadists," Asian Stud. Rev., 2017.

[8] Rony K. Pratama, “(PDF) Terorisme dan Urgensi Pendidikan Literasi,” 2018. [Online]. Available:

https://www.researchgate.net/publication/326476806_Terorisme_dan_Urgensi_Pendidikan_Lite rasi. [Accessed: 03-Apr-2020]. 